East African Community Law

Emmanuel Ugirashebuja, John Eudes Ruhangisa, Tom Ottervanger, and Armin Cuyvers - 9789004322073 Downloaded from Brill.com04/26/2023 11:52:59AM via free access 
The Editors are grateful to Allen \& Overy LLP, the European Union and the Europa Institute of the University of Leiden for making Open Access publication of this book possible.

\section{ALLEN \& OVERY}
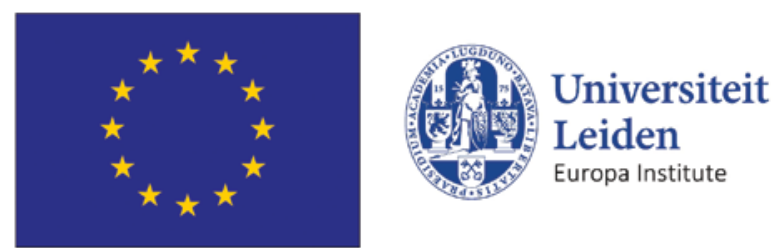

This is an open access title distributed under the terms of the Creative Commons Attribution-Noncommercial 4.0 Unported License (CC-BY-NC), which permits any non-commercial use, distribution, and reproduction in any medium, provided the original author(s) and sources are credited. 


\title{
East African Community Law
}

Institutional, Substantive and Comparative EU Aspects

\author{
Edited by \\ Emmanuel Ugirashebuja \\ John Eudes Ruhangisa \\ Tom Ottervanger \\ Armin Cuyvers
}

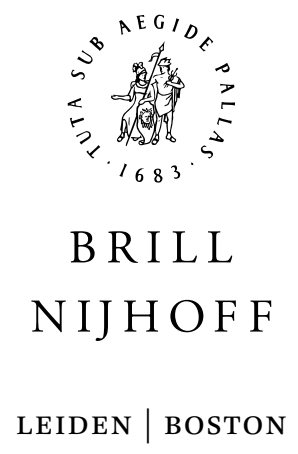


B R I L L Copyright 2017 by Emmanuel Ugirashebuja, John Eudes Ruhangisa, Tom Ottervanger, and O P E N Armin Cuvyers

Library of Congress Cataloging-in-Publication Data

Names: Ugirashebuja, Emmanuel, editor.

Title: East African Community law : institutional, substantive and comparative EU aspects / Edited by Emmanuel Ugirashebuja, John Eudes Ruhangisa, Tom Ottervanger, Armin Cuyvers.

Description: Leiden : Brill Nijhoff, 2017. | Includes bibliographical references and index.

Identifiers: LCCN 2017000988 (print) | LCCN 2017001613 (ebook) | ISBN 9789004322066 (hardback : alk. paper) | ISBN 9789004322073 (E-book)

Subjects: LCSH: Law—East African Community. | Law-European Union countries. | International and municipal law_East African Community. |

Law-International unification. | Comparative law.

Classification: LCC KQC117 .E27 2017 (print) | LCC KQC117 (ebook) | DDC $349.2676-\mathrm{dc} 23$

LC record available at https://lccn.loc.gov/2017000988

Typeface for the Latin, Greek, and Cyrillic scripts: “Brill”. See and download: brill.com/brill-typeface.

ISBN 978-90-04-32206-6 (hardback)

ISBN 978-90-04-32207-3 (e-book)

Koninklijke Brill NV incorporates the imprints Brill, Brill Hes \& De Graaf, Brill Nijhoff, Brill Rodopi and Hotei Publishing.

All rights reserved. No part of this publication may be reproduced, translated, stored in a retrieval system, or transmitted in any form or by any means, electronic, mechanical, photocopying, recording or otherwise, without prior written permission from the publisher.

Authorization to photocopy items for internal or personal use is granted by Koninklijke Brill NV provided that the appropriate fees are paid directly to The Copyright Clearance Center, 222 Rosewood Drive, Suite 910, Danvers, MA 01923, USA. Fees are subject to change.

This book is printed on acid-free paper and produced in a sustainable manner. 


\section{Contents}

Preface IX

Notes on Contributors XI

1 The Road to East African Integration 1

Wanyama Masinde and Christopher Otieno Omolo

1A The Road to European Integration 22

Armin Cuyvers

2 The Institutional Framework of the EAC 43

Wilbert T.K. Kaahwa

2A The Institutional Framework of the EU 79

Armin Cuyvers

3 The Legal Framework of the EAC 103

Elvis Mbembe Binda

3A The Legal Framework of the E $U \quad 119$

Armin Cuyvers

4 The Scope, Nature and Effect of EAC Law 139 John Eudes Ruhangisa

4A The Scope, Nature and Effect of E U Law 161 Armin Cuyvers

$5 \quad$ External Relations and the EAC 182 Leonard Obura Aloo

5A External Relations and the EU 196 Armin Cuyvers

6 General Principles Governing EAC Integration 202 Khoti Chilomba Kamanga and Ally Possi

6A General Principles of EU Law 217

Armin Cuyvers 
7 Judicial Protection under EAC Law: Direct Actions 229 John Eudes Ruhangisa

7A Judicial Protection under EU Law: Direct Actions 254 Armin Cuyvers

8 Preliminary References under EAC Law 265 Emmanuel Ugirashebuja

8A Preliminary References under EU Law 275 Armin Cuyvers

9 The EAC Common Market 285

Kennedy Gastorn and Wanyama Masinde

9A The EU Common Market 293 Armin Cuyvers

10 Free Movement of Goods in the EAC 303 Leonard Obura Aloo

10A Free Movement of Goods in the EU $\quad 326$ Armin Cuyvers

11 Free Movement of Workers in the EAC 345 Caroline Kago and Wanyama Masinde

11A Free Movement of Persons in the E U 354 Armin Cuyvers

12 Freedom of Establishment and the Freedom to Provide Services in the EAC 365 Kennedy Gastorn

12A Freedom of Establishment and the Freedom to Provide Services in the $\mathbf{E} \mathbf{U} \quad 376$

Armin Cuyvers 
13 Free Movement of Capital and East African Monetary Union 392 Elvis Mbembe Binda

13A Free Movement of Capital and Economic and Monetary Union in the EU 410 Armin Cuyvers

14 EAC Competition Law 433 Joyce Karanja-Ng'ang'a

14A EU Competition Law 454

Pieter Van Cleynenbreugel

15 Judicial Enforcement and Implementation of EAC Law 467 James Otieno-Odek

16 Harmonization in the EAC 486 Aleem Tharani

Bibliography 501

Index 536 
Emmanuel Ugirashebuja, John Eudes Ruhangisa, Tom Ottervanger, and Armin Cuyvers - 9789004322073 Downloaded from Brill.com04/26/2023 11:52:59AM via free access 


\section{Preface}

The East African Community (EAC) is a regional intergovernmental and supranational organization currently comprising the Republics of Burundi, Kenya, Rwanda, South Sudan, the United Republic of Tanzania, and the Republic of Uganda. Established in 2000, the EAC aims at widening and deepening cooperation among its Partner States in, among others, political, economic and social fields.

The organization has established a Customs Union (2005) and a Common Market (2010), and is in the process of establishing a Monetary Union. Its ultimate objective is to establish a complete political (con)federation. It emphasizes strong participation of the private sector and civil society. The accomplishment of these objectives requires an elaborate and functionallypurposed institutional framework.

The EAC aims at far deeper integration than envisioned by its predecessor, whilst simultaneously avoiding the mistakes that led to the failure of previous attempts at East African integration. Important safeguards include a gradual approach to integration and guarantees to ensure an equitable division of the benefits of integration.

There is a general consensus that the European Union (EU) was an important source of inspiration and provided a normative model for the EAC. Indeed the EAC Treaty and the Protocols have adopted and adapted significant parts of the EU's institutional and legal framework. The normative appeal of the EU in this regard can also be readily understood. Despite all the past and present failures and challenges facing the $\mathrm{EU}$, no objective observer can deny the benefits of European integration in terms of peace, stability and prosperity. What started 60 years ago as a Community between six Member States in a Europe destroyed by two world wars has now developed into the most peaceful and prosperous block in the world.

Consequently, there are lessons to be learned from the European experience, including the crucial role of the law and of lawyers in the process of integration, be they judges, lawmakers, civil servants, academics or practitioners. The law is one of the most powerful and indispensable instruments to achieve true integration, as effective integration requires some form of supranational legal system. That is what we mean by "Integration through law". Awareness of the possibilities the law offers, therefore, is extremely important for any form of regional integration. 
The main challenges facing the EAC today in this regard are how to safeguard the quality of the increasing body of Community law, how to monitor compliance, and how to make EAC law binding and enforceable within national legal systems. All of these are challenges that the EU has faced in the past and is still facing, and where both the success and the failures of the EU may be of comparative use to the EAC, certainly considering the many similarities in the institutional and legal framework of both and the similarities of the challenges faced.

The main purpose of this book, initiated by the Leiden Centre for the Comparative Study of EAC law (LEAC) in close cooperation with Hon. Justice Dr Ugirashebuja, the current President of the East African Court of Justice, is to be a source of information and education for all those involved in shaping, improving and studying integration in the EAC. By comparing each aspect of both institutional and substantive EAC law with its nearest counterpart EU law, we hope to have created a vital tool to better understand and move forward the integration process in East Africa.

Considering these aims, we are proud that, thanks to the generous support of the law firm Allen \& Overy LLP, the European Union and the Europa Institute of the University of Leiden, this book will not just be available in printed form but will also be freely available online via a completely Open Access agreement with Brill Publishers.

We have been fortunate to find excellent authors from the different EAC Partner States, all leading experts in their respective fields, enabling us to cover all legal aspects of the EAC. We are very grateful for their wonderful contributions and constructive participation in this ambitious project. In addition, we have greatly benefitted from the excellent research and editorial assistance provided by Ties Boonzajer Flaes, Louise O'Callaghan, Brenden Fourie, Timothy Kawira, Carlota de Paula Coelho, and Merel Valk, as research assistants of the LEAC. We are much indebted to them for, among other things, ensuring consistency between the chapters. As always, however, responsibility for the final product remains with the authors and editors.

\section{Emmanuel Ugirashebuja \\ John Eudes Ruhangisa \\ Tom Ottervanger \\ Armin Cuyvers}

November, 2016 


\title{
Notes on Contributors
}

\author{
Leonard Obura Aloo
}

Lecturer, School of Law, University of Nairobi; Legal Practitioner, Mwaura \& Wachira Advocates, Nairobi, Kenya.

\section{Elvis Mbembe Binda}

The author is a trained lawyer and a lecturer at the School of Law of the University of Rwanda where he teaches i.a Economic and Financial Law with an emphasis on the EAC regional economic integration. He obtained a $\mathrm{PhD}$ at the University of Utrecht and is President of the Initiative for Peace and Human Rights (IPHR).

\section{Armin Cuyvers}

Assistant professor of EU law at the Europa Institute of Leiden University; Co-Director of the Leiden Center for East African Community Law (LEAC); PhD, Leiden; Mjur Oxford; Visiting Fellow "European Political Strategy Centre" of the European Commission (Brussels).

\section{Kennedy Gastorn}

Secretary General of the Asian-African Legal Consultative Organization (AALCO). The author was previously a Professor at the University of Dar es Salaam where he headed the Department of Public Law of the School of Law. The views expressed are purely those of the author and may not in any circumstances be regarded as stating an official position of the AALCO.

\section{Wilbert T.K. Kaahwa}

Former Counsel to the East African Community (July 2000-January 2015). He now works as the Director and Lead Consultant for M/s Attune Interlink Consultants Limited in which capacity he has been engaged as Senior Legal Consultant at the African Development Bank (Abidjan, Cote d'Ivoire), as Legal Advisor by M/s sAI Consulting Engineers Pvt Limited (Ahmedabad, India) and M/s Carelink Uganda Limited (Kampala, Uganda).

\section{Caroline Kago}

Chairperson Department of Private Law, Kenyatta University School of Law, Nairobi, Kenya, Advocate of the High Court of Kenya. The Author is a PHD Candidate at the University of the Witwatersrand, and holds an LL.M from the University of Western Cape, South Africa, and an LL.B University of Nairobi. 


\section{Khoti Chilomba Kamanga}

Associate Professor, Department of Public Law, University of Dar es Salaam. Ph.D., Patrice Lumumba University (Moscow), LL.M. in European Union Law, University of Amsterdam.

\section{Joyce Karanja- Ng'ang'a}

Partner and Head of Competition, Bowmans Kenya, Advocate of the High Court of Kenya, member: Law Society of Kenya, International Bar Association. Author: Mergers and Acquisitions Review, Kenya Chapter (2015), The African and Middle Eastern Antitrust Review 2014: Kenya Issues and Challenges in Competition, The COMESA Merger Assessment Guidelines, 2014 explained; The American Bar Association: Essentials of Merger Review (2011,2012), Nature of Law: Broadcasting Regulations (2010), Reform of Kenyan Company Law (2011).

\section{Wanyama Masinde}

Director of the Centre for Regional Integration, Founding Director of the Institute for Regional Integration and Development (IRID) at the Catholic University of Eastern Africa, Nairobi, Kenya. The author also served as a Regional Integration Policy and Strategy Advisor to the Government of Kenya, is a Visiting Professor at several academic institutions in Africa, including the UN Africa Institute for Economic Planning \& Development.

\section{James Otieno-Odek}

Judge of the Court of Appeal and Director of the Judiciary Training Institute of the Republic of Kenya. He is also an Associate Professor of Law at the University of Nairobi. The views expressed are purely those of the author and may not in any circumstances be regarded as stating the position of the Judiciary Kenya or the University of Nairobi.

\section{Christopher Otieno Omolo}

Lecturer at the Institute for Regional Integration and Development (IRID) at the Catholic University of Eastern Africa (CUEA), Nairobi, Kenya; Coordinator of the IRID Master of Arts program in Regional Integration. The author holds a Master of Public Policy (specializing in European Public Policy and International Affairs and Development) from the Willy Brandt School of Public Policy at the University of Erfurt, Germany, and a B.A. from the University of Zimbabwe. 


\section{Tom Ottervanger}

Of Counsel and former Partner at the law firm Allen \& Overy LLP (Brussels/ Amsterdam); Professor of European and Competition law at the Europa Institute of Leiden University; Chair of the Leiden Center for East African Community Law (LEAC); Visiting Professor LuIss University, Rome; deputyJustice at the Court of Appeal in The Hague.

\section{Ally Possi}

The author (LLB (Mzumbe), LLM Cape Town) is an advocate of the High Court and a lecturer at the Law School of Tanzania. He has a PhD from the University of Pretoria. The major area of his research concerns human rights and aspects of international courts.

\section{John Eudes Ruhangisa}

Judge of the High Court of Tanzania; Founding Registrar of the East African Court of Justice 2001-2014; former professor of law at Tumaini-Makumira University, Tanzania, Visiting Professor at i.a Pretoria University (South Africa), Tanzania-German Centre for Postgraduate Studies in Law (TGCL) (Dar es Salaam), Catholic University (CUEA) (Nairobi). He has written extensively on human rights, constitutional law, environmental law, regional integration. $\mathrm{PhD}$ in law from the University of London (sOAs). The views expressed are purely those of the author and may not in any circumstances be regarded as stating the position of the Tanzanian judiciary.

\section{Aleem Tharani}

Partner in the Corporate and Commercial Department of Anjarwalla \& Khanna, specialized in energy, natural resources and infrastructure project development and finance. The author inter alia holds a Postgraduate Diploma in Law from the Kenya School of Law (2006), a Diploma in Legal Practice (Dist.) from Nottingham Law School, UK (2006) and an LL.B (Hons.), from the Victoria University of Manchester, UK (2005).

\section{Emmanuel Ugirashebuja}

President of the East African Court of Justice, previously inter alia Dean of the Law School, University of Rwanda (2009-2014); former Member of the Superior Council of Judiciary (2009-2014); Member of the Supreme Council of prosecution (2009-2014); and Senior Lecturer at the National University of Rwanda. The author holds a PhD and an LLM in Law from the University of Edinburgh, and an LLB. From the University of Rwanda. 


\section{Pieter Van Cleynenbreugel}

The author (Ph.D., KU Leuven, LL.M, Harvard) is Professor of European Union law at the University of Liège, Belgium, where he also presides the Institut d'Etudes Juridiques Européennes. Previously, assistant professor at the Europa Institute, Leiden University. His research focuses on the public and private enforcement of competition law and on EU administrative law. 